\title{
HUBUNGAN BUDAYA ORGANISASI DAN MOTIVASI KERJA DENGAN KINERJA GURU SPK PAMULANG- TANGERANG SELATAN
}

\author{
Zuesty Haryana \\ hestytobing81@gmail.com \\ Said Hutagaol \\ sodoguron_45@yahoo.co.id, UKI \\ Hotmaulina Sihotang \\ hotmaulina.sihotang@uki.ac.id, UKI
}

\begin{abstract}
The formation of intelligence capabilities in education world besides the family as important role, it is school organisation. The school is an alternative educational service institution that has a vision, mission, goals and functions. To carry out its mission, realise its vision, achieve its goals, and carry out its functions, schools need professionals and resources that support both financially and non-financially to achieve common goals. Therefore this study seeks to uncover the relationship between organizational culture and work motivation with teacher performance measured individually or collectively in a school. This study was conducted on 47 teachers of SPK Pamulang-Tangerang Selatan with random sampling techniques. From the results of the comparison, Ho's decision was rejected, they are the relationship between organisational culture and teacher performance, and the relationship between work motivation with teacher performance. This is evidenced from the significant level value of $0.001<\alpha(0.05)=0.05$. Based on the result, it can be concluded that the null hypothesis was rejected, because the results of the hypothesis testing indicate that there is a positive and significant relationship between Organisational Culture, Work Motivation along with the Teacher's Performance in SPK Pamulang-Tangerang Selatan.
\end{abstract}

Keywords: Organizational Culture, Work Motivation, Teacher Performance 


\section{A. PENDAhuluan}

Pembentukan kemampuan inteligensi dalam dunia pendidikan yang utama selain keluarga adalah organisasi sekolah. Sekolah merupakan salah satu lembaga alternatif pelayanan pendidikan yang memiliki visi, misi, tujuan dan fungsi. Untuk mengemban misi, mewujudkan visi, mencapai tujuan, dan menjalankan fungsinya, diperlukan sebuah budaya organisasi yang kuat. Budaya organisasi sendiri dapat muncul ketika nilai-nilai (values) karakter diaplikasikan oleh anggota dari suatu organisasi tersebut. Kepmendiknas (2010: i-ii) menetapkan 18 nilai karakter tersebut yaitu : religius, jujur, toleransi, disiplin, kerja keras, kreatif, mandiri, demokratis, rasa ingin tahu, semangat nasionalisme, cinta tanah air, menghargai prestasi, komunikatif, cinta damai, gemar membaca, peduli lingkungan, peduli sosial, dan tanggung jawab.

Oleh karena itu guru sebagai tenaga pendidik seharusnya telah memiliki kemampuan profesional seperti yang dinyatakan dalam Peraturan Pemerintah Nomor 19 Tahun 2005 tentang Standar Nasional Pendidikan Pasal 28 ayat (3), yang diperoleh melalui pendidikan, pelatihan dan pengembangan diri yang baik; kemauan dan kemampuan untuk merancang, melaksanakan, dan mengevaluasi pembelajaran; serta kemauan dan kemampuan lain yang terkait dengan tugas dan tanggung jawabnya. Hal tersebut membutuhkan motivasi kerja yang kuat dan dinamis.

\section{B. PEMBAHASAN}

Sekolah merupakan salah satu organisasi yang bertujuan membuat perubahan dalam bidang pendidikan. Sebagai bagian dari organisasi, sekolah memerlukan pengelolaan budaya organisasi yang sesuai dengan budaya masing-masing sekolah tersebut seperti dalam Peraturan Menteri Pendidikan Nasional nomor 19 tahun 2007 tentang standar pengelolaan pendidikan oleh Satuan Pendidikan Dasar dan Menengah "Sekolah wajib menyusun dan melaksanakan program kerja RKS/RKJM (Rencana Kerja Jangka Menengah) dan RKT/RKAS (Rencana Kerja Tahunan/Anggaran Sekolah) yang memuat tentang Pengembangan Budaya dan Lingkungan Sekolah". Dalam penjelasannya, Budaya Sekolah adalah (standar) perilaku profesional (akademik dan administratif/manajerial) dan sosial yang mapan di sekolah untuk mencapai tujuan sekolah yang didasarkan pada kesepakatan atas nilai-nilai dan keyakinan bersama yang positif.

Budaya sekolah sangat berkaitan dengan asumsi-asumsi, nilai-nilai, norma, perilaku, dan kebiasaan-kebiasaan (positif) di sekolah. Budaya sekolah akan dipengaruhi dengan iklim sekolah yang mengacu kepada suasana lingkungan internal sekolah, baik dari segi fisik maupun sosial (yang kondusif). Dalam peraturan tersebut juga dijelaskan nilai-nilai Budaya Positif Sekolah seperti religius, akademis, demokratis, disiplin, jujur, bersih, sehat, kerja keras, kolaboratif, toleran, menghargai inovasi, transparan, bertanggung jawab, berbagi, cinta lingkungan, cinta tanah air, dan semangat kebangsaan. Jika Budaya Positif dan Iklim Kondusif bergabung dan dilaksanakan maka kepuasaan kerja 
meningkat, pergaulan lebih akrab, disiplin meningkat, pengawasan fungsional berkurang, keinginan selalu berbuat positif tumbuh, efektifitas belajar dan berprestasi berkembang, keinginan warga sekolah memberikan yang terbaik bagi sekolah, keluarga, orang lain dan diri sendiri meningkat, serta kepercayaan diri meningkat baik secara individu maupun sebagai warga sekolah.

Susanto (2016:70), perspektif kebijakan pendidikan nasional, pemerintah merumuskan empat jenis kompetensi guru sebagaimana tercantum dalam Penjelasan Peraturan No. 19 Tahun 2005 tentang Standar Nasional Pendidikan, yaitu: Kompetensi Pedagogik, kompetensi yang harus dikuasai guru meliputi pemahaman guru terhadap siswa, perancangan dan pelaksanaan pembelajaran, evaluasi hasil belajar dan pengembangan siswa untuk mengaktualisasikan berbagai potensi yang dimilikinya. Kompetensi Kepribadian, kemampuan personal yang mencerminkan kepribadian yang mantap, stabil, dewasa, arif, berakhlak mulia dan berwibawa, dan dapat menjadi teladan bagi siswa. Kompetensi Sosial, kemampuan yang harus dimiliki guru untuk berkomunikasi dan bergaul secara efektif dengan siswa, sesama pendidik, tenaga kependidikan, orang tua/wali siswa, dan masyarakat sekitar. Kompetensi Profesional, kemampuan penguasaan materi pembelajaran secara luas dan mendalam yang harus dikuasai guru mencakup penguasaan materi kurikulum mata pelajaran disekolah dan substansi keilmuan yang menaungi materi, serta penguasaan terhadap struktur dan metodologi keilmuan.

Didalam peningkatan kualitas atau kemampuan guru, ada beberapa faktor yang mempengaruhi dan harus diperhatikan oleh manajemen organisasi tentang kebutuhan dan kepuasan tiap individu pekerja, Gibson (2010:190), membahas teori Abraham Maslow yang mengaitkan motivasi dengan lima kebutuhan manusia berdasarkan hirarkinya: Maslow's hierarchy of needs is a motivational theory in psychology comprising a five-tier model of human needs, often depicted as hierarchical levels within a pyramid. Needs lower down in the hierarchy must be satisfied before individuals can attend to needs

Agustus 2019 higher up. From the bottom of the hierarchy upwards, the needs are: physiological, safety, love and belonging, esteem and self-actualization. Hirarki kebutuhan Maslow adalah teori motivasi dalam psikologi yang terdiri dari model lima tingkat kebutuhan manusia, sering digambarkan sebagai tingkat hirarki dalam piramida. Kebutuhan yang lebih rendah dalam hirarki harus dipenuhi sebelum suatu individu dapat memenuhi kebutuhan yang lebih tinggi. Dari bawah ke atas, kebutuhannya adalah: fisiologis, keamanan, cinta dan kepemilikan, penghargaan dan aktualisasi diri.

\section{METODE PENELITIAN}

Dalam metode pengumpulan data yang digunakan pada penelitian ini menggunakan pendekatan kuantitatif dengan metode survei dan dianalisa menggunakan analisis (Uji) statistik deskriptif dan korelasi dengan cara penyebaran kuesioner.

\section{HASIL PENELITIAN}

Penelitian ini menggunakan tabel critical value dengan taraf signifikan $5 \%$ dengan jumlah responden $20(\mathrm{n})$, yakni $\mathrm{r}_{(0,05,20-2)}$ dari tabel product moment 
adalah 0,468. Jika koefisien $r_{\text {hitung }}$ yang didapatkan lebih besar dari $r_{\text {tabel }}$ atau critical value maka dapat disimpulkan adanya korelasi. Maka butir soal yang memiliki nilai $r_{\text {hitung }}>r_{\text {tabel }}$ dinyatakan valid. Sebaliknya jika nilai butir soal bernilai $r_{\text {hitung }}<r_{\text {tabel }}$ tidak akan digunakan atau dihapus dari butir soal.

Setelah mengetahui butir soal yang valid, maka dilakukan pengujian reliabilitas terhadap soal butir yang valid sebanyak 83 (delapan puluh tiga) soal dengan menggunakan Cronbach Alpha $(\alpha)$. Suatu instrumen akan dinyatakan reliabel jika nilai a minimal 0.6 (Siregar, 2013:55). Penghitungan $\alpha$ dalam penelitian ini dilakukan dengan menggunakan program Microsoft Excel, setelah dilakukan penghitungan variansi dari masing-masing butir soal dan variansi total, maka penghitungan $\alpha$ dilakukan menggunakan rumus Cronbach Alpha. Adapun nilai $\alpha$ pada ketiga variabel adalah 0,960 untuk Kinerja Guru, 0.939 untuk Budaya Organisasi dan 0,957 untuk Motivasi Kerja. Maka dapat disimpulkan bahwa instrumen kinerja guru, budaya organisasi, dan motivasi kerja adalah reliabel. Adapun nilai $X^{2}{ }_{\text {hitung }}$ ketiga variabel adalah 55.478 untuk kinerja guru, 4.688 untuk budaya organisasi dan 7.6574 untuk motivasi kerja. Derajat kebebasan (df) setiap variabel adalah sama yaitu 6 , maka $X^{2}$ tabel dengan taraf signifikan 0.05 adalah 12.592 Maka dari ketiga variabel dapat ditarik kesimpulan bahwa data berdistribusi normal, karena masing-masing variabel memiliki $X^{2}{ }_{\text {hitung }}<X^{2}$ tabel. Hasil data dari penelitian diperoleh dari ukuran skala Likert dengan skala nilai 1 menyatakan sangat tidak setuju, nilai 2 menyatakan tidak setuju, nilai 3 menyatakan netral, nilai 4 menyatakan setuju, dan niali 5 menyatakan sangat setuju. Data didapatkan dari jawaban responden atas 83 (delapan puluh tiga) butir soal yang digunakan untuk mengukur 2 (dua) variabel independen yaitu Budaya Organisasi dan Motivasi Kerja dan 1 (satu) variabel dependen Kinerja Guru.

Dimensi KG1 (kompetensi pedagogik) dengan 8 butir soal dan jumlah jawaban yang masuk dari 47 guru sebanyak $376(8 \times 47)$ jawaban, diperoleh modus berupa skor 4 (49\%) yang berarti hampir setengah bagian dari guru menjawab skor 4 . Sebanyak 49\% guru setuju memiliki Kompetensi Pedagogik. Persentase guru yang memilih jawaban 4 dan 5 sebesar $95 \%$, maka dapat disimpulkan sebagian besar guru SPK Pamulang- Tangerang Selatan setuju dan sangat setuju jika dikatakan memiliki Kompetensi Pedagogik dalam kinerjanya melaksanakan proses pembelajaran.

Dimensi KG2 (Kompetensi Kepribadian) dengan 6 butir soal dan jumlah jawaban yang masuk dari 47 guru sebanyak 282 (6x47) jawaban, memiliki modus skor 4 $(52 \%)$ ) yang berarti setengah lebih sedikit guru setuju memiliki Kompetensi Kepribadian. Persentase guru yang memilih jawaban 4 dan 5 sebesar 93\%, maka dapat disimpulkan setengah dari jumlah guru SPK Pamulang-Tangerang Selatan setuju dan sangat setuju memiliki Kompetensi Kepribadian yang sesuai dengan norma yang berlaku dalam berperilaku pada proses pembelajaran.

Dimensi KG3 (Kompetensi Sosial) dengan 6 butir soal dan jumlah jawaban yang masuk dari 47 guru sebanyak 282 (4x47) jawaban, memiliki modus skor $4(50 \%)$ yang berarti setengah guru setuju memiliki Kompetensi Sosial. Persentase guru yang memilih jawaban 4 dan 5 sebesar 96\%, data menunjukkan mayoritas guru harus memiliki Kompetensi Sosial sebagai kemampuan kinerja guru dalam menilai, berkomunikasi dan bertindak pada proses pembelajaran.

Dimensi KG4 (Kompetensi Profesionalitas) dengan 8 butir soal dan jumlah jawaban yang masuk dari 47 guru sebanyak 376 (8x47) jawaban, memiliki modus 
skor $4(54 \%)$ yang berarti setengah lebih sedikit setuju memiliki Kompetensi Profesionalitas. Persentase guru yang memilih jawaban 4 dan 5 sebesar 95\%, berdasarkan hasil data menunjukkan bahwa guru SPK Pamulang-Tangerang Selatan sangat setuju memiliki Kompetensi Profesionalitas yang mampu mengoperasikan dan menggunakan teknologi informasi dalam mengembangkan kinerjanya melalui proses pembelajaran.

Dimensi BO1 (Inovasi) dengan 4 butir soal dan jumlah jawaban yang masuk dari 47 guru sebanyak 188 (4x47) jawaban, memiliki modus skor 4 (57\%) yang berarti setengah lebih sedikit setuju menciptakan inovasi. Persentase guru yang memilih jawaban 4 dan 5 sebesar 95\%, berdasarkan hasil data menunjukkan bahwa guru SPK Pamulang- Tangerang Selatan sangat setuju memiliki Budaya Organisasi Inovasi untuk mengembangkan diri dan mampu menciptakan ide baru serta berkreatifitas dalam proses pembelajaran.

Dimensi BO2 (Stabilitas) dengan 4 butir soal dan jumlah jawaban yang masuk dari 47 guru sebanyak 188 (4x47) jawaban, memiliki modus skor 4 (54\%) yang berarti setengah lebih sedikit setuju memiliki stabilitas kerja. Persentase guru yang memilih jawaban 4 dan 5 sebesar 93\%, berdasarkan hasil data menunjukkan bahwa guru SPK Pamulang-Tangerang Selatan setuju menjaga Budaya Organisasi Stabilitas dalam menjalankan peraturan sekolah pada proses pembelajaran.

Dimensi BO3 (Orientasi Tim) dengan 4 butir soal dan jumlah jawaban yang masuk dari 47 guru sebanyak 188 (4x47) jawaban, memiliki modus skor 4 (54\%) yang berarti setengah lebih sedikit setuju memiliki Orientasi Tim. Persentase guru yang memilih jawaban 4 dan 5 sebesar 97\%, berdasarkan hasil data menunjukkan bahwa guru SPK Pamulang-Tangerang Selatan sangat setuju pada Budaya Organisasi Orientasi Tim dikarenakan bagi guru SPK Pamulang-Tangerang Selatan, guru harus menunjukkan sikap saling mendukung dan menghargai dalam tim pada proses pembelajaran.

Dimensi BO4 (Orientasi Hasil) dengan 4 butir soal dan jumlah jawaban yang masuk dari 47 guru sebanyak 141 (3x47) jawaban, memiliki modus skor $4(57 \%)$ yang berarti setengah lebih sedikit setuju memiliki Orientasi Hasil. Persentase guru yang memilih jawaban 4 dan 5 sebesar 89\%, berdasarkan hasil data menunjukkan bahwa guru SPK Pamulang-Tangerang Selatan rata-rata setuju pada Budaya Organisasi Orientasi Hasil untuk fokus dalam target hasil pekerjaan dalam proses pembelajaran. Adapun sisanya sebesar $11 \%$ guru bersikap netral (antara setuju dan tidak setuju).

Dimensi BO5 (Perilaku) dengan 4 butir soal dan jumlah jawaban yang masuk dari 47 guru sebanyak 188 (4x47) jawaban, memiliki modus skor $4(51 \%)$ yang berarti setengah lebih sedikit setuju menjaga perilaku. Persentase guru yang memilih jawaban 4 dan 5 sebesar 93\%, berdasarkan hasil data menunjukkan bahwa guru SPK Pamulang- Tangerang Selatan setuju menjaga Budaya Organisasi melalui perilaku dan menciptakan iklim kerja yang kondusif dalam proses pembelajaran.

Dimensi BO6 (Kepedulian) dengan 4 butir soal dan jumlah jawaban yang masuk dari 47 guru sebanyak 188 (4x47) jawaban, memiliki modus skor $4(53 \%)$ yang berarti setengah lebih sedikit setuju memiliki stabilitas kerja. Persentase guru yang memilih jawaban 4 dan 5 sebesar $85 \%$, berdasarkan hasil data menunjukkan bahwa guru SPK Pamulang-Tangerang Selatan dalam sikap Budaya Organisasi Kepedulian, bersedia menjadi analisator dan bekerja secara detail pada proses pembelajaran. Sedangkan 15\% guru memilih bersikap netral terhadap Budaya 
Organisasi tersebut dikarenakan banyaknya program akademik dan non-akademik yang dijalankan secara bersamaan.

Dimensi BO7 (Orientasi Kolaborasi) dengan 4 butir soal dan jumlah jawaban yang masuk dari 47 guru sebanyak 188 (4x47) jawaban, memiliki modus skor 4 (51\%) yang berarti setengah lebih sedikit setuju memiliki stabilitas kerja. Persentase guru yang memilih jawaban 4 dan 5 sebesar 98\%, berdasarkan hasil data menunjukkan bahwa guru SPK Pamulang-Tangerang Selatan sangat setuju menjalankan Budaya Organisasi Orientasi Kolaborasi pada proses pembelajaran karena dengan berkolaborasi tercipta kerjasama dan saling menghargai dalam sebuah tim.

Dimensi MK1 (Kebutuhan Fisiologis) dengan 4 butir soal dan jumlah jawaban yang masuk dari 47 guru sebanyak 188 (4x47) jawaban, memiliki modus skor 4 (52\%) yang berarti setengah lebih sedikit setuju tercukupinya Kebutuhan Fisiologis. Persentase guru yang memilih jawaban 4 dan 5 sebesar $73 \%$, berdasarkan hasil data menunjukkan bahwa guru SPK Pamulang-Tangerang Selatan sebagian besar setuju telah memiliki Kebutuhan Fisiologis yang tercukupi. Sedangkan sisanya sebesar $27 \%$ merasa ragu-ragu dan belum tercukupi kebutuhannya sehingga menyatakan bahwa motivasi kerja mereka belum optimal.

Dimensi MK2 (Kebutuhan Keamanan) dengan 6 butir soal dan jumlah jawaban yang masuk dari 47 guru sebanyak 282 (6x47) jawaban, memiliki modus skor 4 (55\%) yang berarti setengah lebih sedikit setuju mendapatkan Kebutuhan Keamanan. Persentase guru yang memilih jawaban 4 dan 5 sebesar $85 \%$, berdasarkan hasil data menunjukkan bahwa guru SPK Pamulang-Tangerang Selatan sebagian besar setuju telah memiliki Kebutuhan Keamanan yang baik. Sedangkan sisanya sebesar $15 \%$ merasa ragu-ragu telah mendapatkan rasa aman dalam bekerja dan mendapatkan fasilitas kesehatan yang terjamin sehingga menyebabkan motivasi kerja mereka belum maksimal.

Dimensi MK3 (Kebutuhan Sosial) dengan 6 butir soal dan jumlah jawaban yang masuk dari 47 guru sebanyak 282 (6x47) jawaban, memiliki modus skor $4(61 \%)$ yang berarti setengah lebih banyak setuju telah memiliki Kebutuhan Sosial. Persentase guru yang memilih jawaban 4 dan 5 sebesar $87 \%$, berdasarkan hasil data menunjukkan bahwa guru SPK Pamulang-Tangerang Selatan sebagian besar setuju telah memiliki Kebutuhan Sosial yang baik. Sedangkan sisanya sebesar $13 \%$ merasa ragu-ragu dan merasa belum diakui keberadaannya di lingkungan kerja sehingga menyatakan bahwa motivasi kerja mereka belum terealisasikan.

Dimensi MK4 (Kebutuhan Penghargaan) dengan 6 butir soal dan jumlah jawaban yang masuk dari 47 guru sebanyak $282(6 \times 47)$ jawaban, memiliki modus skor 4 (52\%) yang berarti setengah lebih sedikit setuju memiliki Kebutuhan Penghargaan. Persentase guru yang memilih jawaban 4 dan 5 sebesar 80\%, berdasarkan hasil data menunjukkan bahwa guru SPK Pamulang-Tangerang Selatan sebagian besar setuju telah memiliki Kebutuhan Penghargaan yang baik. Sedangkan sisanya sebesar $20 \%$ merasa ragu-ragu dan belum memperoleh penghargaan atas hasil yang dicapainya serta nilai yang sesuai dengan pekerjaannya sehingga menyatakan bahwa motivasi kerja mereka belum maksimal.

Dimensi MK5 (Kebutuhan Aktualisasi Diri) dengan 6 butir soal dan jumlah jawaban yang masuk dari 47 guru sebanyak 282 (6x47) jawaban, memiliki modus skor $4(59 \%)$ yang berarti setengah lebih sedikit setuju memiliki Kebutuhan 
Aktualisasi Diri. Persentase guru yang memilih jawaban 4 dan 5 sebesar 83\%, berdasarkan hasil data menunjukkan bahwa guru SPK Pamulang-Tangerang Selatan sebagian besar setuju telah memiliki Kebutuhan Aktualisasi Diri yang baik. Sedangkan sisanya sebesar $17 \%$ merasa ragu-ragu dan belum memperoleh kesempatan untuk mengembangkan diri serta promosi jabatan dari hasil kerjanya sehingga menyatakan bahwa motivasi kerja mereka belum maksimal.

\section{Hubungan Budaya Organisasi dengan Kinerja Guru akan dijelaskan dalam} tabel berikut:

Tabel UJI PARSIAL $\mathrm{X}_{1}$ terhadap $\mathrm{Y}$

\begin{tabular}{lc}
\hline F-hitung & 0,4897 \\
\hline F-tabel(alpha,k,df) & \\
\hline F-tabel $(0.05,1,44)$ & 4.06 \\
\hline
\end{tabular}

Berdasarkan data yang ditunjukkan oleh tabel, hubungan atau korelasi antara budaya organisasi dengan kinerja guru yang dihitung dengan koefisien korelasi sebesar 4,897 Koefisien ini lebih besar dari nilai $r_{\text {tabel }}$ untuk 47 responden yaitu sebesar 0,28 maka karena hasil perbandingan $\mathbf{r}_{\text {hitung }}=\mathbf{4 , 8 9 7}>\mathbf{r}_{\text {tabel }}=\mathbf{0 , 2 8}$ dapat disimpulkan bahwa ditemukan adanya hubungan antara Budaya Organisasi dengan Kinerja Guru SPK

Pamulang-Tangerang Selatan. Hubungan antara budaya organisasi dengan kinerja guru cukup kuat karena berada di antara 0,40 - 0,599. Artinya hubungan positif adalah hubungan searah, yaitu semakin baik hubungan maka semakin baik kinerja guru. Dari hasil perbandingan, ternyata Sig $=\mathbf{0 , 0 0 7}<\boldsymbol{\alpha}_{(\mathbf{0 , 0 5})}=\mathbf{0 , 0 5}$ sehingga keputusannya Ho ditolak, yaitu hubungan antara budaya organisasi dengan kinerja guru.

\section{Hubungan Motivasi Kerja dengan Kinerja Guru akan dijelaskan dalam tabel berikut:}

\begin{tabular}{|c|c|}
\hline F-hitung Tabel UЛ & $\theta, \$$ zerhadap 1 \\
\hline Ftabel(alpha,k,df) & \\
\hline F-tabel $(0.05,1,44)$ & 4.06 \\
\hline
\end{tabular}

Berdasarkan data yang ditunjukkan oleh tabel, hubungan atau korelasi antara motivasi kerja dengan kinerja guru yang dihitung dengan koefisien korelasi sebesar 0,462 Koefisien ini lebih besar dari nilai $r_{\text {tabel }}$ untuk 47 responden yaitu sebesar 0,28 maka karena hasil perbandingan $\mathbf{r}_{\text {hitung }}=\mathbf{0 , 4 6 2}>\mathbf{r}_{\text {tabel }}=\mathbf{0 , 2 8}$ dapat disimpulkan bahwa ditemukan adanya hubungan antara Motivasi Guru dengan Kinerja Guru SPK Pamulang- Tangerang Selatan.

hubungan antara motivasi kerja dengan kinerja guru cukup kuat karena berada di antara 0,40-0,599. Artinya hubungan positif adalah hubungan searah, yaitu semakin baik hubungan maka semakin baik kinerja guru. Dari hasil perbandingan, ternyata $\mathbf{S i g}=\mathbf{0 , 0 0 0 3}<\boldsymbol{\alpha}_{(\mathbf{0 , 0 5})}=\mathbf{0 , 0 5}$ sehingga keputusannya Ho ditolak, yaitu hubungan antara motivasi kerja dengan kinerja guru. 


\section{Hubungan Budaya Organisasi dan Motivasi Kerja dengan Kinerja Guru secara bersama-sama akan dijelaskan dalam tabel berikut:}

Tabel Uji Korelasi Secara Bersama-sama Perhitungan F-hitung

\begin{tabular}{|l|l|l|}
\hline $\mathrm{N}$ & jumlah sampel & 47 \\
\hline $\mathrm{R}$ & koefisien korelasi & 0.4197627 \\
\hline $\mathrm{m}$ atau $\mathrm{k}$ & jumlah variabel bebas & 2 \\
\hline Df & derajat kebebasan & 44 \\
\hline Alpha & & 0.05 \\
\hline & F-hitung & 5.6744904 \\
\hline & F-tabel(alpha,k,df) & \multicolumn{2}{|l}{} \\
\cline { 2 - 3 } & F-tabel(0.05,2,44) & 3.21 \\
\hline
\end{tabular}

Sumber: Pengolahan data 2019

Berdasarkan data yang ditunjukkan oleh tabel, uji korelasi diperoleh variabel Budaya Organisasi $\left(\mathrm{X}_{1}\right)$ dengan Kinerja Guru (Y) dan Motivasi Kerja (X2) dengan Kinerja Guru (Y) memiliki nilai sig=0,419 dimana nilai taraf resiko (signifikan) $\alpha$ sebesar 0,05 . Hasil menunjukkan taraf signifikan yang diperoleh adalah untuk Budaya Organisasi $\left(\mathrm{X}_{1}\right)$ adalah 0,007 yang berarti lebih kecil dari 0,05 dan Motivasi Kerja $\left(\mathrm{X}_{2}\right)$ adalah 0,0003, maka dapat disimpulkan bahwa ditemukan adanya hubungan yang signifikan antara Budaya Organisasi dengan Kinerja Guru, dan demikian juga antara Motivasi Guru dengan Kinerja Guru SPK Pamulang-Tangerang Selatan.

Subyek dari penelitian ini adalah guru tetap dan tidak tetap yang mengajar di sekolah tersebut dan menghasilkan pernyataan dari kuesioner yang disebarkan serta menghasilkan penelitian bahwa kinerja guru secara keseluruhan di SPK Pamulang- Tangerang Selatan dikategorikan baik, yaitu dengan rata-rata Likert 4,39 dan modus 4 yang berarti $90 \%$ guru telah memahami tugasnya dengan baik dan menjalankan kewajiban dengan bertanggung jawab. Hasil penilaian tersebut bukan berarti seluruh guru telah menjalankan tugas dan tanggung jawabnya dengan baik. Berdasarkan jawaban responden, sebagian guru belum maksimal dan sempurna dalam mengelola pembelajaran secara efektif dikarenakan kurangnya pemahaman akan Kompetensi Dasar dan Kurikulum mata pelajaran yang diampu. Budaya Organisasi yang diterapkan SPK Pamulang-Tangerang Selatan secara umum menyatakan memiliki budaya yang cukup kuat dan baik, yaitu dengan ratarata Likert 4,34 dan modus 4 dengan persentase 80-90\%. Sekolah berorientasi kepada kerjasama tim dan kolaborasi dalam proses pembelajaran bukan kepada hasil. Dengan hal tersebut guru dapat bekerja, berinovasi dan berkreasi tanpa adanya paksaan konsep tertentu dalam menentukan kreasi mereka. Sekolah memberikan kesempatan kepada guru untuk mengembangkan dirinya. Namun ada juga guru berdasarkan jawaban dari pernyataan kuesioner merasakan bahwa sekolah belum maksimal mempertahankan stabilitas sehingga timbul rasa kepedulian yang sangat minim dalam tim kerja.

Sedangkan Motivasi Kerja yang digambarkan SPK Pamulang-Tangerang Selatan 
secara umum memiliki motivasi yang cukup dan baik, yaitu dengan rata-rata skala Likert 4,07 dan modus 4 dengan perentase $80-90 \%$. Dari hasil jawaban pernyataan responden dinyatakan ada guru yang tidak puas dengan pendapatannya (gaji) padahal sekolah berperan penting dalam menimbulkan motivasi kerja guru. Notoatmodjo (2015:124-125) mengemukakan bahwa keberhasilan suatu instansi atau organisasi ditentukan oleh dua faktor utama, yakni sumber daya manusia (karyawan atau tenaga kerja) serta sarana dan prasarana pendukung atau fasilitas kerja. Namun demikian dalam kenyataannya, dari banyak penelitian membuktikan bahwa faktor gaji merupakan faktor yang dominan dalam mencapai kepuasan kerja (job satisfaction) bagi seorang pegawai.

\section{E. KESIMPULAN, IMPLIKASI, DAN SARAN}

Berdasarkan hasil dari analisa data dan pengujian hipotesis, maka dapat disimpulkan, bahwa: Dari hasil pengujian hipotesis membuktikan adanya hubungan positif yang cukup kuat dan signifikan antara Budaya Organisasi (X1) dengan Kinerja Guru (Y) SPK Pamulang-Tangerang Selatan. Koefisien korelasi antara dua variabel tersebut pada taraf signifikan $\alpha=0,05$ adalah sebesar 0,007 . Dari hasil pengujian hipotesis membuktikan adanya hubungan yang positif cukup kuat dan signifikan antara Motivasi Kerja (X2) dengan Kinerja Guru (Y) SPK Pamulang-Tangerang Selatan. Koefisien korelasi antara dua variabel tersebut pada taraf signifikan $\alpha=0,05$ adalah sebesar 0,0003 . Dari hasil pengujian hipotesis membuktikan adanya hubungan yang positif cukup kuat dan signifikan secara bersama antara Budaya Organisai (X1) dan Motivasi Kerja (X2) dengan Kinerja Guru (Y) SPK Pamulang-Tangerang Selatan. Koefisien korelasi antara dua variabel tersebut pada taraf signifikan $\alpha=0,05$ adalah sebesar 0,966 dan koefisien determinasi sebesar 0,390 serta persamaan $\mathrm{Y}=64.710 .+0.335 \mathrm{X} 1+0.157 \mathrm{X} 2$. Persamaan memperlihatkan bahwa 96\% kinerja guru dapat dijelaskan oleh budaya organisasi dan motivasi kerja.

Implikasi dari penelitian ini dapat dikemukakan secara langsung dan tidak langsung. Implikasi Secara langsung diharapkan guru dapat melaksanakan dan mengembangkan kinerja berdasarkan kompetensi guru sehingga mampu mengefektifkan metode pembelajaran yang tepat. Sedangkan secara tidak langsung, budaya dan motivasi kerja mempengaruhi kinerja guru tersebut secara signifikan.

Maka berdasarkan hasil kesimpulan di atas, dapat diungkapkan beberapa saran, yaitu sebagai berikut: Budaya kolaborasi dan kerjasama adalah budaya yang paling dominan dan sebaiknya dipertahankan. Sedangkan untuk budaya saling peduli satu dengan yang lainnya perlu ditingkatkan. Dalam hal ini sekolah dapat melegalkannya dan masuk dalam pedomana guru sehingga sekolah secara langsung memberikan motivasi atau dorongan kepada guru sesuai hasil penilaian sehingga mendapatkan upah layak yang dapat meningkatkan kinerja guru dalam melaksanakan tugas dan tanggung jawabnya. Motivasi kerja yang paling dominan adalah diakuinya keberadaan diri di lingkungan kerja dan sebaiknya dipertahankan. Sedangkan motivasi akan kebutuhan aktualisasi perlu diperhatikan oleh sekolah terhadap guru yang benar-benar memiliki potensi dalam bidangnya. Sehingga kesempatan dalam berkarir memacu tiap individu guru menunjukkan kehebatan atau skill masing-masing. Guru dalam berkinerja memiliki dominan untuk kreatif dan efektif dalam mengajar, dan hal ini sangat perlu dipertahankan. 
Kompetensi profesional harus terus ditingkatkan karena pemikiran siswa masa kini berkembang pesat seiring berkembangnya teknologi, maka disarankan untuk selalu up to date dalam perkembangan ilmu informasi teknologi.

\section{DAFTAR PUSTAKA}

Made Pidarta, 2007. Landasan Kependidikan. Jakarta: Rineka Cipta.

Susanto, Ahmad, 2016. Manajemen Peningkatan Kinerja Guru. Jakarta : Prenadamedia Group.

Chantarath Hongboontri and Natheeporn Keawkhong, 2014. "School Culture: Teachers' Beliefs, Behaviors, and Instructional Practices". A Journal, Australian Journal of Teacher Education Vol.39 Issue 5.

Siregar, Syofian, 2013. Metode Penelitian Kuantitatif. Jakarta: Kencana.

Gibson, James L., Donnelly, James H., Ivancevich, John M, 2010. Organisasi : Behavior, Structure, process. Organisasi Jilid 1, Bab V, terjemahan. Tangerang: Binarupa Aksara.

Notoatmodjo, Soekidjo, 2015. Pengembangan Sumber Daya Manusia. Jakarta: PT Rineka Cipta. 